\title{
Skewed X-Chromosome Inactivation in a Korean Girl with Severe Mucopolysaccharidosis Type II
}

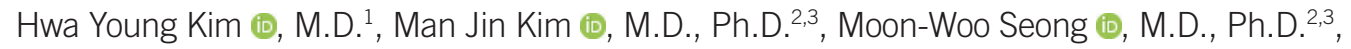 \\ and Jung Min Ko (i), M.D., Ph.D., \\ Departments of ${ }^{1}$ Pediatrics, ${ }^{2}$ Laboratory Medicine, and ${ }^{3}$ Rare Disease Center, Seoul National University Hospital, Seoul National University College of \\ Medicine, Seoul, Korea
}

\section{Dear Editor,}

Mucopolysaccharidosis type II (MPS II, Hunter syndrome, OMIM 309900) is a multisystem disorder caused by deficient production or activity of the lysosomal hydrolase iduronate 2-sulfatase, encoded by the IDS gene [1]. Most affected individuals are males owing to the X-linked inheritance; however, females, while rare, can also be affected due to chromosomal rearrangement or skewed X-chromosome inactivation (XCl) [1]. The rarity of MPS II incidence in females has contributed to the limited experience regarding the use of enzyme replacement therapy (ERT) in only five female patients, who experienced short-term outcomes (ERT duration from 7 months to 2 years and 8 months) [2-5]. Here, we describe the case of a girl with a severe MPS II phenotype resulting from IDS-IDS2 recombination and skewed XCl and treated with ERT for over six years (initiated immediately after diagnosis). The Institutional Review Board of Seoul National University Hospital (SNUH), Seoul, Korea approved the current study (IRB No: 2012-108-1197), and informed consent was obtained from the parents of the patient.

A 41-month-old girl was referred to the genetics clinic of SNUH for investigation of dysostosis multiplex. The patient was the firstborn child of healthy non-consanguineous parents. At the time of visit, the patient showed delayed speech development and was noted to have coarse facies, multiple persistent Mongolian spots, a mild umbilical hernia, multiple joint contractures, and hepatosplenomegaly. Echocardiography revealed mild mitral regurgitation with anterior mitral leaflet thickening and prolapse. A magnetic resonance imaging brain scan revealed an enlarged perivascular space in both the genu of the corpus callosum and periventricular white matter. The urine glycosaminoglycan analysis result was positive, and plasma iduronate 2-sulfatase activity was very low ( $1.8 \mathrm{nmol} / 4$ hours/mg protein; age matched control: $496.3 \pm 165.7 \mathrm{nmol} / 4$ hours/mg protein). Enzyme test results for $\alpha$-iduronidase, $\alpha$ - $\mathrm{N}$-acetylglucosaminidase, $\beta$-galactosidase, arylsulfatase B, and $\beta$-glucuronidase excluded MPS I, MPS IIIB, MPS IV, MPS VI, and MPS VII, respectively.

The chromosome microarray analysis results revealed that the karyotype is normal. Sequence analysis of IDS revealed no variants. IDS-IDS2 recombination was identified using a PCR assay [6]. The identified variant resulted from a recombination between IDS and the IDS2 pseudogene, leading to an inversion between sequences in intron 7 of IDS and sequences near exon 3 of IDS2 (Fig. 1A). The proband's mother was a wild-type homozygote, indicating a de novo event in the patient. X-inactivation analysis was performed using PCR to evaluate a highly polymorphic CAG repeat in the first exon of the androgen receptor $(A R)$ gene [7].
Received: July 6, 2021

Revision received: August 4, 2021

Accepted: November 29, 2021

Corresponding author: Jung Min Ko, M.D., Ph.D. Department of Pediatrics, Seoul National University Children's Hospital, 101 Daehak-ro, Jongno-gu, Seoul 03080, Korea Tel: +82-2-2072-7592, Fax: +82-2-743-3455

E-mail: jmko@snu.ac.kr

\section{(c) (1) $(9$}

(C) Korean Society for Laboratory Medicine

This is an Open Access article distributed under the terms of the Creative Commons Attribution Non-Commercial License (https://creativecommons.org/licenses/by-nc/4.0) which permits unrestricted non-commercial use, distribution, and reproduction in any medium, provided the original work is properly cited. 

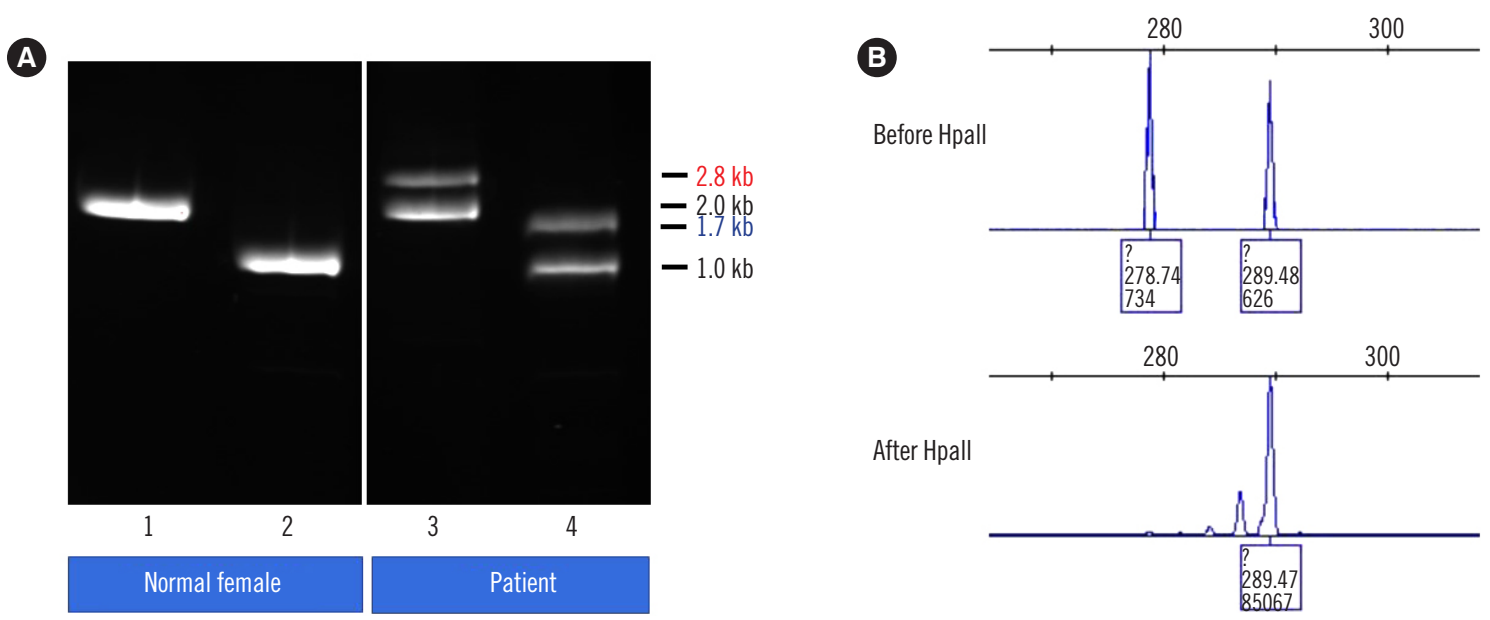

Fig. 1. Genetic analysis of IDS-IDS2 recombination and X-chromosome inactivation. (A) PCR amplification of the inversion junctions shows recombinant fragments containing the proximal $(2.8 \mathrm{~kb})$ and distal $(1.7 \mathrm{~kb})$ junctions. Lanes 1 and 2: PCR amplification from a normal female [1: proximal region $(2.0 \mathrm{~kb}), 2$ : distal region $(1.0 \mathrm{~kb})$ ]. Lanes 3 and 4: PCR amplification of the current patient (3: proximal recombination, 4: distal recombination). (B) X-chromosome inactivation analysis shows extremely skewed X-inactivation. Before Hpall: undigested DNA; After Hpall: Hpall-digested DNA.

Table 1. Sequences of PCR primers used to amplify the polymorphic CAG repeat in the first exon of the $A R$ gene

\begin{tabular}{lc}
\hline Locus & \multicolumn{1}{c}{ Primer sequence } \\
\hline$A R$ & Forward: 5'-TCCAGAATCTGTCCAGAGCGTGC-3' \\
& Reverse: 5'-GCTGTGAAGGTGCTGTCCTCAT-3'
\end{tabular}

The PCR conditions was as follows: initial denaturation at $94^{\circ} \mathrm{C}$ for 5 minutes, 35 cycles consisting of denaturation at $94^{\circ} \mathrm{C}$ for 30 seconds, annealing at $55^{\circ} \mathrm{C}$ for 60 seconds, and extension at $72^{\circ} \mathrm{C}$ for 90 seconds, and a final cycle of $72^{\circ} \mathrm{C}$ for 5 minutes and $60^{\circ} \mathrm{C}$ for 45 minutes (Table 1). PCR products of both digested and undigested DNA were subjected to an ABI PRISM 3130 Genetic Analyzer (Applied Biosystems, Foster City, CA, USA) and analyzed using GeneMapper Software v.3.7 (Applied Biosystems). The methylation pattern of Hpall sites close to the highly polymorphic CAG repeat revealed an extremely skewed $\mathrm{XCl}$ pattern (>95:5) (Fig. 1B).

At the age of 3 years and 7 months, the patient started ERT that continued for 6 years and 7 months. The treatment was well-tolerated and resulted in disease stabilization at follow-up. At the age of 10 years and 2 months, the hepatosplenomegaly was resolved, and physical endurance was maintained with improvement of the joint contractures. However, the patient exhibited growth retardation, mild left ventricular systolic dysfunction requiring medication, and persistent intellectual disability.

There have been few reports regarding female patients with MPS II, most of which have been caused by preferential XCl of the non-mutant allele. High genetic heterogeneity is observed in females with MPS II, including intragenic sequence variants, inversion variants, indels, and chromosomal translocation [3, 5, 8]. The IDS-IDS2 recombination found in our patient, which is the most frequently observed variant in Korean patients with MPS II, has been commonly associated with severe forms of the disorder $[2,4,9]$. The extreme variant and skewed $\mathrm{XCl}$ in our patient were likely responsible for her severe phenotypic manifestation. ERT using recombinant human iduronate 2-sulfatase has resulted in improvement of lung function, organomegaly, joint mobility, and physical endurance, and is more effective when started early [10]. Similar improvements as those reported for male patients have been reported in a few studies that treated female patients, which is in accordance with our patient [2-5]. However, enzyme delivery to the brain and other tissues with low vascularization, such as cardiac valves, bone, and cartilage, is limited, resulting in limited efficacy of ERT in those organs. This is also consistent with the results demonstrated in our patient. ERT administered via intrathecal injection and gene therapy are currently under investigation in effort to overcome these limitations [1].

In conclusion, we report a case in Korea of a female patient with MPS II and a severe phenotype caused by skewed $\mathrm{XCl}$. This report highlights the importance of considering a diagnosis of MPS II and the early initiation of treatment in any female presenting with the related clinical symptoms. Further studies are needed to elucidate the molecular pathogenesis of preferred inactivation of the non-mutant allele in female patients with MPS II. 


\section{ACKNOWLEDGMENTS}

We express our gratitude to the patient and her parents for their participation in the study.

\section{AUTHOR CONTRIBUTIONS}

Kim HY and Ko JM conceptualized the study and collected the data. Kim HY wrote the manuscript. Kim MJ and Seong MW contributed to the data analysis and interpretation. All authors have read and consented to the final manuscript.

\section{CONFLICTS OF INTEREST}

None declared.

\section{RESEARCH FUNDING}

This work was supported by the Seoul National University Hospital Research Fund (grant number 800-20210295).

\section{ORCID}

Hwa Young Kim

Man Jin Kim

Moon-Woo Seong

Jung Min Ko https://orcid.org/0000-0003-3238-5315 https://orcid.org/0000-0002-9345-6976 https://orcid.org/0000-0003-2954-3677 https://orcid.org/0000-0002-0407-7828

\section{REFERENCES}

1. D’Avanzo F, Rigon L, Zanetti A, Tomanin R. Mucopolysaccharidosis type II: one hundred years of research, diagnosis, and treatment. Int J Mol Sci 2020;21:1258.

2. Manara R, Rampazzo A, Cananzi M, Salviati L, Mardari R, Drigo P, et al. Hunter syndrome in an 11-year old girl on enzyme replacement therapy with idursulfase: brain magnetic resonance imaging features and evolution. J Inherit Metab Dis 2010;33(S3):S67-72.

3. Jurecka A, Krumina Z, Żuber Z, Różdżyńska-Świątkowska A, Kłoska A, Czartoryska B, et al. Mucopolysaccharidosis type II in females and response to enzyme replacement therapy. Am J Med Genet A 2012;158A 450-4.

4. Julien DC, Woolgar K, Pollard L, Miller H, Desai A, Lindstrom K, et al. Immune modulation for enzyme replacement therapy in a female patient with Hunter syndrome. Front Immunol 2020;11:1000.

5. Piña-Aguilar RE, Zaragoza-Arévalo GR, Rau I, Gal A, Alcántara-Ortigoza MA, López-Martínez MS, et al. Mucopolysaccharidosis type II in a female carrying a heterozygous stop mutation of the iduronate-2-sulfatase gene and showing a skewed X chromosome inactivation. Eur J Med Genet 2013;56:159-62.

6. Lagerstedt K, Karsten SL, Carlberg BM, Kleijer WJ, Tönnesen T, Pettersson $\mathrm{U}$, et al. Double-strand breaks may initiate the inversion mutation causing the Hunter syndrome. Hum Mol Genet 1997;6:627-33.

7. Allen RC, Zoghbi HY, Moseley AB, Rosenblatt HM, Belmont JW. Methylation of Hpall and Hhal sites near the polymorphic CAG repeat in the human androgen-receptor gene correlates with $\mathrm{X}$ chromosome inactivation. Am J Hum Genet 1992;51:1229-39.

8. Sohn YB, Kim SJ, Park SW, Park HD, Ki CS, Kim CH, et al. A mother and daughter with the p. R443X mutation of mucopolysaccharidosis type II: genotype and phenotype analysis. Am J Med Genet A 2010; 152A:3129-32.

9. Sohn YB, Ki CS, Kim CH, Ko AR, Yook YJ, Lee SJ, et al. Identification of 11 novel mutations in 49 Korean patients with mucopolysaccharidosis type II. Clin Genet 2012;81:185-90.

10. Stapleton M, Kubaski F, Mason RW, Yabe H, Suzuki Y, Orii KE, et al. Presentation and treatments for mucopolysaccharidosis type II (MPS II; Hunter syndrome). Expert Opin Orphan Drugs 2017;5:295-307. 